
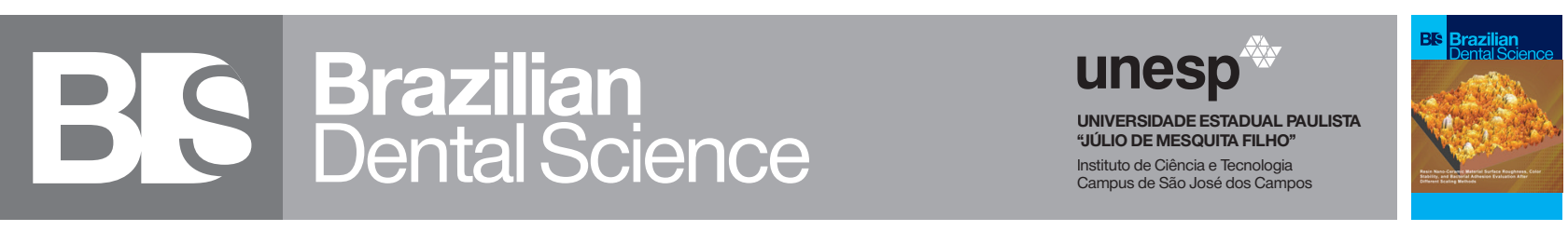

\title{
Awareness of medical emergencies among dental practitioners in three Egyptian dental schools: A cross-sectional study
}

\author{
Conscientização sobre emergências médicas entre dentistas em três Faculdades de Odontologia Egípcias: um estudo transversal
}

\author{
Heba HUSSEIN ${ }^{1}$, Mohamed A.ABDELBAQY' ${ }^{2}$, Abdelrahman A. IBRAHIM ${ }^{3}$, Shahenda M. FARID ${ }^{4}$, Suzan S IBRAHIM ${ }^{5}$ \\ 1 - Oral Medicine and Periodontology Department, Faculty of Dentistry, Cairo University, Cairo, Egypt \\ 2 - Alexandria Regional Centre for Women Health and Development, Cairo, Egypt \\ 3 - Oral Medicine and Periodontology Department, Faculty of Oral and Dental medicine, Al Ahram Canadian University, Cairo, Egypt \\ 4 - Oral Medicine and Periodontology Department, Faculty of Dentistry, Ain Shams University, Cairo, Egypt \\ 5 - Oral Medicine and Periodontology Department, Faculty of Dentistry, Ain Shams University, Cairo, Egypt. Faculty of Oral and Dental \\ Medicine, Nahda University In Beni Suef, Egypt.
}

\begin{abstract}
Objective: To evaluate the awareness of medical emergencies among dental practitioners in three dental schools. Material and methods: The study group included 384 dental practitioners, including dental staff members, post-graduate students, and dental interns. These professionals were attending three dental educational institutions in Egypt. Two of them were governmental and one was a private school. The educational model is almost the same in most Egyptian dental schools. Results: The response rate was $100 \%$. Most of the participants worked in private academia $(44.16 \%)$ or practice $(42.34 \%)$ and $65.20 \%$ of them were females. The participants who recorded the medical history and filled a form (91.17\%, $80.52 \%$ respectively) while only $41.82 \%$ obtained the vital signs. Among the participants, 48.57 $\%$ were confident about handling medical emergency and $74.29 \%$ reported their capability of intramuscular injection while only $25.71 \%$ for intravenous injection and $49.35 \%$ knew about emergency kits. Management knowledge of airway obstruction and prosthetic heart valve patients was reported by $80.27 \%$ and 71.94 $\%$ respectively, while less percentage for activation of EMS, chest compression, CPR ratio, and infant rescue breathing. The mean preparedness percent score was $54.57 \%$ and it was inversely correlated to the years of experiences and directly correlated to the degree of confidence in their ability to manage the dental emergency. Conclusion: The current study results reflected a deficiency in the dental practitioner awareness about the medical emergency especially the practical part.
\end{abstract}

\section{KEYWORDS}

Dentists; Cross-sectional studies; Emergencies; Educational models; Dental schools.

\section{RESUMO}

Objetivo: Avaliar a consciência das emergências médicas entre os dentistas de três faculdades de odontologia. Material e Métodos: O grupo de estudo incluiu 384 dentistas, abrangendo membros da equipe odontológica, alunos de pós-graduação e estagiários de odontologia. Esses profissionais frequentavam três instituições de ensino de odontologia no Egito. Duas eram governamentais e uma era uma instituição particular. O modelo educacional é similar na maioria das escolas de odontologia egípcias. Resultados: A taxa de resposta foi de $100 \%$. A maioria dos participantes trabalhava na área acadêmica $(44,16 \%)$ ou clínica privadas $(42,34 \%)$ e $65,20 \%$ deles eram do sexo feminino. Os participantes registraram o histórico médico e preencheram um formulário (91,17\%, 80,52\% respectivamente) enquanto apenas $41,82 \%$ obtiveram os sinais vitais. Entre os participantes, $48,57 \%$ estavam confiantes para lidar com emergências médicas e 74,29\% relataram sua capacidade de injeção intramuscular, enquanto apenas $25,71 \%$ para injeção intravenosa e 49,35\% sabiam sobre kits de emergência. O conhecimento do manejo de pacientes com obstrução das vias aéreas e válvula cardíaca protética foi relatado por $80,27 \%$ e $71,94 \%$, respectivamente, enquanto menos porcentagem para a ativação do serviço de emergência médica (SEM), compressão torácica, índice de reanimação cardiorrespiratória (RCP) e respiração de resgate infantil. A pontuação percentual média de preparação foi de $54,57 \%$ e foi inversamente correlacionada aos anos de experiência e diretamente correlacionada ao grau de confiança em sua capacidade de gerenciar a emergência odontológica. Conclusão: Os resultados do presente estudo refletiram uma deficiência na conscientização do dentista sobre a emergência médica principalmente a parte prática.

\section{PALAVRAS-CHAVE}

Odontólogos; Estudos transversais; Emergências; Modelos educacionais; Faculdades de odontologia. 


\section{INTRODUCTION}

A

$\mathrm{n}$ emergency is a medical condition that requires prompt attention and successful management. Since the number of elderly and medically compromised patients is increasing, the frequency of medical emergencies in the dental practice is also increasing [1]. It is the utmost responsibility of dental practitioners to sustain life until medical help arrives in order to reduce chances of mortality and morbidity $[2,3]$.

The increasing number of medical emergencies can be attributed to the increase in the average age of the patients undergoing dental treatment which is associated with the rising number of medications administered to them, and their possible side effects [4]. In addition to the invasive procedures in the dental office which might result in medical emergencies [5].The most common medical emergencies in dental practice are syncope, adverse reactions to local anesthesia (LA), grand mal seizures, angina pectoris, and hypoglycemia $[6,7]$. The extent of treatment by dentists requires both the prevention and management of medical emergencies. Hypertension and coronary heart disease affect $25 \%$ and $8.5 \%$ of the Egyptian population respectively increasing the probability of sudden cardiac arrest during dental therapy [8].

Dental practitioners face the risk of coming in contact with medical emergency events. These emergencies are unpredictable, should be managed instantly, and cannot be referred as they expose the life and the health of patients to danger and lead to emotional stress to the dental practitioners facing these serious episodes which require continuous awareness and preparedness of the dental team about their nature and proper maneuver of their management [3,9-11]. Dental practitioners have the duty of identifying medical emergencies once they arise, along with being competent in managing them optimally $[12,13]$.
Dental practitioners worldwide still have inadequate ability to cope with many types of medical emergencies $[14,15]$. Ghanem E. et al. in 2018 concluded that there was a poor level of knowledge about Basic Life Support (BLS) skills among Egyptian medical students [16]. In recent decades, there is a dramatic shift in the method of teaching medical emergency management to undergraduate students in many developed countries in an attempt to improve their management outcomes [17]. Establishing a proper well-known action plan prior to dealing with a medical emergency in the dental office along with training all dental staff about it to know their roles in an urgency, are crucial in emergency management $[18,19]$.

Diminishing the incidence of medical emergencies in the dental office can be attempted by obtaining a full medical history including medication use. This medical history must be performed using both a written questionnaire and oral discussion. Furthermore, measuring vital signs and performing visual inspection of the patient may disclose a hidden condition the patient may not know and may expose him to a crucial event during dental treatment [18].

The important aspects of medical emergencies in dental practice are to prevent or to correct the inadequate oxygenation of brain and heart tissues [12]. For ensuring the delivery of oxygenated blood to critical organs, the dentist must be competent in basic cardiopulmonary resuscitation (CPR) [5]. After the ABCs (airway, breathing, circulation), emergency drugs should be the next consideration in medical emergency management [20]. Thus, the aim of this study was to evaluate the awareness of medical emergencies among dental practitioners in three dental schools and to assess participants' preparedness for medical emergencies in dental practice. Our research hypothesis was that there was a need for more and different types of training to both the undergraduate and postgraduate dental students. 


\section{MATERIAL AND METHODS}

\section{Ethical considerations}

The research has been revised and approved by the Research Ethics Committee, Faculty of Dentistry, Cairo University on 30 October 2018 (\#18-10-52.) All the participants were informed about the nature of the study and agreed to participate through a verbal consent after confirming the confidentiality of the obtained data.

\section{Study design and setting}

This is a cross-sectional questionnairebased study on convenience sampling of dental practitioners in Cairo, Egypt. Questionnaire distribution was performed between the period of November 2018 and May 2019. The study followed the Strengthening and Reporting of Observational Studies in Epidemiology (STROBE) statement guidelines during the preparation of this study.

\section{Participants}

The study group included 384 dental practitioners, including dental staff members, post-graduate students, and dental interns. These professionals were attending three dental educational institutions in Egypt. Two of them were governmental and one was a private school. The educational model is almost the same in most Egyptian dental schools.

\section{Data acquisition}

A standard questionnaire in the English language was adapted from a previous study [21]. The questionnaire included four parts. Part A was about the demographics of participants. Part B was about case history and vital signs registry (seven questions). Part $\mathrm{C}$ included questions regarding the availability of emergency drug kits (seven questions). Part D included questions about BLS training and important practice in common medical emergencies in the dental office (eleven questions). This gave a total of twenty five medical emergencyrelated questions. The questionnaire included the following topics: Emergency training and management, most common medical emergencies in the dental office, CPR, systemically compromised conditions and their management, and availability of emergency drugs. The questionnaire consisted mainly of objective questions, requiring a simple yes or no reply.

The face validity of the questionnaire was assessed by a pilot study of twenty participants to ensure language interpretation. All questions were comprehended by the participants with no confusion. The questionnaire was developed based on a previous study which already had content validity and its reliability determined using Cronbach's alpha coefficient test with a value of 0.82 [21].

\section{Data analysis}

With a precision of 5\%, a 95\% confidence interval, a design effect of 1 and unknown prevalence of level of awareness level of dental emergencies $(50 \%$ is used to ensure the highest number), the minimum estimated sample size was 384 participants. Data analysis has been done by Statistical Package for Social Sciences (SPSS) (version 20 for windows). Results were analyzed using an answer key, numerical variables. Descriptive statistics were calculated and variables are reported as means (M) and standard deviations (SD), frequencies, and percentages. Pearson correlation was obtained to measure the relationship between different variables. The value $\mathrm{p}<0.05$ was considered statistically significant.

\section{RESULTS}

The response rate of the questionnaire was $100 \%$. The study was conducted on 384 participants and two-third of them were females $(65.20 \%)$. There were three places of data collection at three different dental schools: 
Faculty of Dentistry at Ain Shams University and Faculty of Oral and Dental Medicine at Ahram Candian University had an equal number of participants (137) which is slightly higher than the Faculty of Dentistry at Cairo University (111). The participants were grouped into four groups according to the workplaces with the highest percentage was showed in private work either private academia $(44.16 \%)$ or private practice $(42.34 \%)$. Many participants reported that they have more than one workplace. The majority of the participants (71.69\%) reported that they learned about medical emergency during undergraduate studies as shown in table I.

Regarding the medical history taking, the participants inquired about medical history were $91.17 \%$ and $80.52 \%$ filled a form while only $41.82 \%$ of the participants obtained the vital signs. $48.57 \%$ of the participants were confident that they can handle a medical emergency while $74.29 \%$ reported their capability of intramuscular injection while only $25.71 \%$ reported their capability of intravenous injection. $49.35 \%$ reported their knowledge about emergency kits while $70.39 \%$ reported the availability of glucose (Table II).

A total of $84.7 \%$ of the participants reported that they can manage syncope during dental treatment by placing the patient in a Trendelenburg position and giving ammonia inhalant. Regarding the management of airway obstruction by aspiration of a foreign body and prosthetic heart valve patients before tooth extraction, the answers level were $80.27 \%$ and $71.94 \%$ respectively. The percentage of participants who know about the activation of EMS was $26.75 \%$ (Table III).

Almost half of the participants (51.68\%) answered the question of the chest compression location correctly. Also, 42.6\% answered the adult CPR ratio correctly. While only $24.94 \%$ knew how to give rescue breathing in infants.
The relation between both years of experience and the degree of confident on how to handle emergency condition at dental office and high score of preparedness and awareness level was statistically significant. $(r=-0.109$, $p$ $=0.035 ; \mathrm{r}=0.124, \mathrm{p}=0.016)$ prospectively (Table IV).

Table I - Baseline information

\begin{tabular}{|cccc|}
\hline Question & Answer & No. & $\%$ \\
\hline \multirow{4}{*}{ Gender } & Female & 251 & 65.20 \\
& Male & 134 & 34.80 \\
\hline \multirow{3}{*}{ Place of data collection } & Ain Shams University & 137 & 35.59 \\
& Ahram Canadian University & 137 & 35.59 \\
& Cairo University & 111 & 28.83 \\
\hline Type of workplace * & Academia (private) & 170 & 44.16 \\
& Academia (governmental) & 106 & 27.53 \\
& Practice (private) & 163 & 42.34 \\
\hline No. of years of expe- & Practice (governmental) & 93 & 24.16 \\
\hline rience & 1-less than 5years & 220 & 57.14 \\
& 5less than 20 & 141 & 36.62 \\
\hline When did you learn & More than 20 years & 24 & 6.24 \\
\hline about medical emer- & Undergraduate study & 276 & 71.69 \\
gency? & Post-graduate study & 70 & 18.18 \\
& Self-study & 86 & 22.34 \\
& Continuous education course & 43 & 11.17 \\
\hline
\end{tabular}

* Applicant might have more than one answer (multiple response).

Table II - Case history registration

\begin{tabular}{|c|c|c|c|c|}
\hline \multirow{2}{*}{ Question } & \multicolumn{2}{|c|}{ Yes } & \multicolumn{2}{|c|}{ Yes } \\
\hline & No. & $\%$ & No. & $\%$ \\
\hline $\begin{array}{l}\text { Do you enquire about medical history including } \\
\text { medication and allergy? }\end{array}$ & 351 & 91.17 & 34 & 8.83 \\
\hline $\begin{array}{l}\text { Do you obtain filled health history Performa from the } \\
\text { patients? }\end{array}$ & 310 & 80.52 & 75 & 19.48 \\
\hline Do you obtain the vital signs? & 161 & 41.82 & 224 & 58.18 \\
\hline $\begin{array}{l}\text { Have you attended any workshop on emergency } \\
\text { training or management programs? }\end{array}$ & 251 & 65.19 & 134 & 34.81 \\
\hline $\begin{array}{l}\text { Do you think you can handle any emergency condi- } \\
\text { tion at your dental office? }\end{array}$ & 187 & 48.57 & 198 & 51.43 \\
\hline Can you give an intramuscular injection? & 286 & 74.29 & 99 & 25.71 \\
\hline Can you give an Intravenous injection? & 99 & 25.71 & 286 & 74.29 \\
\hline \multicolumn{5}{|l|}{ Availability of emergency drugs } \\
\hline Adrenaline & 172 & 44.68 & 213 & 55.32 \\
\hline Oral glucose & 271 & 70.39 & 114 & 29.61 \\
\hline Ammonia inhalant: & 117 & 30.39 & 268 & 69.61 \\
\hline Hydrocortisone: & 151 & 39.22 & 234 & 60.78 \\
\hline Epinephrine: & 152 & 39.48 & 233 & 60.52 \\
\hline Atropine: & 95 & 24.68 & 290 & 75.32 \\
\hline
\end{tabular}


Table III - Immediate response to a medical emergency

\begin{tabular}{|c|c|c|c|}
\hline Question & Answer & No. & $\%$ \\
\hline \multirow{5}{*}{$\begin{array}{l}\text { A patient suffered from syncope when you commenced a } \\
\text { dental procedure. What would be your immediate action? }\end{array}$} & Continue dental procedure & 4 & 1.04 \\
\hline & Place patient in Trendelenburg position and give ammonia inhalant ${ }^{\dagger}$ & 326 & 84.68 \\
\hline & Make patient to sit in upright position & 45 & 11.68 \\
\hline & Make patient to stand & 1 & 0.26 \\
\hline & Don'tknow & 9 & 2.34 \\
\hline \multirow{5}{*}{$\begin{array}{l}\text { A patient is cited with airway obstruction during dental } \\
\text { treatment due to aspiration of foreign body what would } \\
\text { you do }\end{array}$} & Attempt Heimlich/Triple maneuver & 29 & 7.53 \\
\hline & Examine mouth and local area & 20 & 5.19 \\
\hline & Ask patient to cough & 20 & 5.19 \\
\hline & All of the above ${ }^{\dagger}$ & 309 & 80.27 \\
\hline & Don'tknow & 7 & 1.82 \\
\hline \multirow{5}{*}{$\begin{array}{l}\text { If you confirm somebody is not responding to you even after } \\
\text { shaking and shouting at him. What will be your immediate } \\
\text { action? }\end{array}$} & Start CPR & 168 & 43.64 \\
\hline & Activate $\mathrm{EMS}^{\dagger}$ & 103 & 26.75 \\
\hline & Put him in recovery position & 68 & 17.66 \\
\hline & Observe & 31 & 8.05 \\
\hline & Don'tknow & 15 & 3.90 \\
\hline \multirow{5}{*}{$\begin{array}{l}\text { How do you plan for extraction of a tooth in patients with } \\
\text { prosthetic heart valve }\end{array}$} & Advise antibiotic prophylaxis & 44 & 11.43 \\
\hline & Ask the patient to stop blood thinners & 5 & 1.30 \\
\hline & Advise the patient to take consent from the general physician & 47 & 12.21 \\
\hline & All of the above ${ }^{\dagger}$ & 277 & 71.94 \\
\hline & Don'tknow & 12 & 3.12 \\
\hline \multirow{5}{*}{$\begin{array}{l}\text { Which of the following dental procedures can be perfor- } \\
\text { med in patients with prosthetic heart valve without giving } \\
\text { antibiotic prophylaxis? }\end{array}$} & Dental radiographs & 19 & 4.94 \\
\hline & Placement of orthodontic brackets & 11 & 2.86 \\
\hline & Placement of removable prosthesis and orthodontic appliances & 7 & 1.81 \\
\hline & All of the above ${ }^{\dagger}$ & 340 & 88.31 \\
\hline & Don’tknow & 8 & 2.08 \\
\hline \multirow{5}{*}{ What is the abbreviation of BLS? } & Best life support & 13 & 3.38 \\
\hline & Basic life support $^{\dagger}$ & 349 & 90.65 \\
\hline & Basic lung support & 6 & 1.56 \\
\hline & Basic life services & 7 & 1.81 \\
\hline & Don'tknow & 10 & 2.60 \\
\hline \multirow{5}{*}{ What is the location of chest compression? } & Left side of the chest & 65 & 16.88 \\
\hline & Right side of the chest & 11 & 2.86 \\
\hline & Mid chest $^{\dagger}$ & 199 & 51.68 \\
\hline & Xiphisternum & 96 & 24.94 \\
\hline & Don’tknow & 14 & 3.64 \\
\hline \multirow{5}{*}{ Ratio of CPR, single rescuer in adult? } & 15:02 & 64 & 16.62 \\
\hline & 05:01 & 46 & 11.95 \\
\hline & $30: 02^{\dagger}$ & 164 & 42.60 \\
\hline & 15:01 & 66 & 17.14 \\
\hline & Don'tknow & 45 & 11.69 \\
\hline \multirow{4}{*}{$\begin{array}{l}\text { If you do not want to give mouth to mouth CPR, the } \\
\text { following can be done except }\end{array}$} & Mouth-mask ventilation and chest compression & 78.00 & 20.26 \\
\hline & Chest compression only & 49.00 & 12.72 \\
\hline & Bag mask ventilation with chest compression & 95.00 & 24.68 \\
\hline & $\mathrm{NoCPR}^{\dagger}$ & 163.00 & 42.34 \\
\hline \multirow{5}{*}{ How do you give rescue breathing in infants? } & Mouth to mouth with nose pinched & 148 & 38.44 \\
\hline & Mouth to mouth and nose ${ }^{\dagger}$ & 96 & 24.94 \\
\hline & Mouth to nose only & 20 & 5.19 \\
\hline & Mouth to mouth without nose pinched & 80 & 20.78 \\
\hline & Don'tknow & 41 & 10.65 \\
\hline
\end{tabular}

\section{${ }^{\dagger}$ Correct answer}


Table IV - Correlation between preparedness score and selected factors

\begin{tabular}{|c|c|c|}
\hline & \multicolumn{2}{|c|}{$\begin{array}{l}\text { Pearson Correlation } \\
\text { Score } \%\end{array}$} \\
\hline & $\begin{array}{l}\text { Correlation } \\
\text { Coefficient }\end{array}$ & $\begin{array}{l}\text { p-value } \\
\text { (Sig.) }\end{array}$ \\
\hline Gender & -0.072 & 0.157 \\
\hline Years of experience & $-0.109^{\star}$ & 0.035 \\
\hline (Type of work) Where do you work? & -0.019 & 0.711 \\
\hline Undergraduate & 0.059 & 0.249 \\
\hline Post graduate & -0.025 & 0.618 \\
\hline Self-study & 0.004 & 0.941 \\
\hline $\begin{array}{l}\text { Have you attended any workshop on emergency } \\
\text { training or management programs? }\end{array}$ & 0.056 & 0.273 \\
\hline Place of data collection & -0.019 & 0.711 \\
\hline $\begin{array}{l}\text { Do you think you can handle any emergency condi- } \\
\text { tion at your dental office? }\end{array}$ & $0.124^{*}$ & 0.016 \\
\hline
\end{tabular}

\section{DISCUSSION}

As health professionals, dentists must be aware that they are dealing with human life, and must consequently assume the risks and responsibilities inherent to their occupation [22]. Medical emergencies in the dental office are not a rare incident and dentists worldwide have to deal with them, from those that are benign to life-threatening conditions such as cardiac arrest [23]. Based on the results presented, the null hypothesis of the present study can be rejected. It can be stated that there is a need for more training for both undergraduate and postgraduate dental students in the selected dental schools.

Many publications on medical emergencies in dental offices have been published. For example, in Germany, Muller et al. stated that $57 \%$ of dentists encounter at least three emergencies per year, and 36\% face more than ten and in France Collange et al., in 2010 concluded that one of each 20 general dental practitioners will have to cope with cardiopulmonary resuscitation at least once during his/her career [13, 24].

Training in emergency management for dental graduates is essential, the dental curricula in many countries include training models for medical emergency management. Yet, the lack of continuous training and inability to cope with medical emergencies can lead to tragic consequences and sometimes legal action [25]. Therefore, the current study aimed to evaluate the degree of awareness of medical emergencies among dental practitioners and their preparedness for management. According to our knowledge, our study is the first to assess the knowledge about medical emergency among dental practitioners in Egypt. Being a multicenter study, its results can be generalized to a wide population of Egyptian dental practitioners.

In the current study, an adapted questionnaire by Varma et al. 2015 was used in which reliability and validity measurements have been already done [21]. The questionnaire included both skills and knowledge sections. A pilot study was conducted by distributing the questionnaire over 20 participants and the questions were completely understandable.

The study group included 384 dental practitioners attending three dental educational schools in Egypt, two of them are the biggest governmental dental schools in Egypt with large numbers of dental staff and graduate students. Both schools get graduate students from all the governorates of Egypt with different types of workplace. One private school was included to increase the generalizability of the tested sample.

In the current study, $71.6 \%$ of the participants had knowledge about medical emergencies during their undergraduate education compared to $74.09 \%$ in the Verma et al study [21]. Both of which is relatively higher when compared to the study done by Gupta et al. [11].

In our study, $91.17 \%$ of the participants inquired about the medical history and $80.52 \%$ filled a form which is very similar to Verma et al. who found that $94.02 \%$ of the participants inquired about the medical history but $67.11 \%$ documented that. However, all the above findings were high when compared to a similar study conducted by Kumarswami et al. which 
was mainly due to the increase in the awareness regarding medical emergencies among dentists [26].

On the other hand, it was found that only $41.82 \%$ obtained the vital signs. This was low compared to the study conducted by Verma et al. where they found $83.06 \%$ recorded vital signs [21]. However, those results were higher than those reported by a Saudi study where they found that only $12 \%$ of the participants take vital signs every visit [27]. Such finding raised the awareness toward the alarming inadequacy of clinic and staff preparation toward medical emergency.

In the current study, $48.57 \%$ of the participants were confident that they can handle a medical emergency. This percent approaches the percent in the study done by Verma et al. which was 49.5\% [21] while Goel and Kroria (2016) had observed that $43.8 \%$ of the participants were confident in dealing with medical emergency themselves whereas the remainders were dependent on others to sustain life in such situations [28].

The present study demonstrated that the attitude of the participants to the capability of intramuscular injections is relatively high $(74.29 \%)$ and nearly the same as that obtained by Verma et al. (73.1\%) [21]. In the contrary, the capability of intravenous injection was just $25.7 \%$ compared to that obtained by Verma et al that was $71.8 \%$ [21]. This reveals the lack of training of the Egyptian dental practitioners to perform intravenous injections before their graduation or during practice.

Only $49.35 \%$ reported the availability of emergency kits. In contrast to Verma et al. where $87.2 \%$ of the practitioners had emergency kits at the dental office to handle medical emergencies [21]. However, the current finding was a much higher percentage compared to the findings $(8.9 \%)$ in a study done by Gbotolorun et al. [29].

Reporting the availability of oral glucose was high $(70.39 \%)$ while reporting of inhalant ammonia, hydrocortisone, epinephrine, and atropine was low $(30.39 \%, 39.22 \%, 39.48 \%$, $24.68 \%$ respectively) compared to the much higher findings in other studies by Verma et al. [21], Kumaraswam [26], and Gupta et al. [11]. This is mostly due to the accessibility of the more available prepared oral glucose solution used in the dental settings.

Concerning immediate response to a medical emergency, $84.68 \%$ of the participants reported that they can manage syncope during dental treatment by placing the patient in Trendelenburg position and giving ammonia inhalant. This is very very similar to results obtained by the study conducted by Verma et al. which was $81.4 \%$. In contrary to both the management of airway obstruction by aspiration of a foreign body $(80.27 \%)$ and the management of prosthetic heart valve patients before tooth extraction $(71.94 \%)$ in which the participants gave a higher percentage than that obtained by Verma et al. which were $61.8 \%$ and 64.4 $\%$ respectively [21]. This may be due to these conditions are the most commonly discussed and encountered in dental practice by most of the participants. However, the knowledge about the activation of EMS was low (26.75\%). This could be explained as EMS is used in the United States as an emergency medical service or 911 but not in Egypt.

The CPR-related knowledge was low especially that related to infancy-CPR. Only $51.69 \%$ of the participants had knowledge of the chest compression location, $42.6 \%$ for the adult CPR ratio and $24.94 \%$ about rescue breathing in infants. That indicates the utmost importance of the reinforcement of a periodic CPR training with special attention to CPR done on infancy. Our results support those results of Breuer et al. [30] and those of Elanchezhiyan et al. 2013 [2] They concluded that Advanced Cardiovascular Life Support (ACLS) training is necessary on a regular basis and it should be a standardized part of the medical emergency curriculum for the dental students and ACLS in life-threatening situations is considered a basic skill for dental professionals $[2,30]$. 
A guided preparedness score was developed based on the participants' answers. We reported the mean medical emergency score percent of $54.57 \%$ in accordance with Goel and Kroria (2016) who had 5.28 score in their study denoting almost half of the dentists participating in this study had insufficient knowledge on handling clinical situations [29].

The correlation analysis showed that the awareness of the medical emergency is inversely proportional with the years of experience denoting lack of mandatory continuing education programs. However, the score was significantly correlated to the degree of confidence in their ability to manage the dental emergency in the dental office.

Although some of the post graduate students from the private practice or governmental hospitals were included in our study, future studies should be conducted with the focus on the general practitioners in private practice or governmental hospitals. This way, the generalization of the results should be done with caution because the research was conducted at educational schools.

\section{CONCLUSION}

The current study results reflected a deficiency in the dental practitioner's awareness about the medical emergency especially the practical part and knowledge about emergency kit or equipment availability.

\section{Recommendations}

- Introduction of medical emergencies problem-based case scenarios and patient's simulation into the undergraduate dental program courses.

- Continuous dental education and training of medical emergencies is a shared responsibility between the ministry of health and the dental educational schools.

- More stringent rules and regulations for emergency preparedness must be reinforced by the involved authorities.
- Medical emergency training courses should be an essential requirement for dental periodic practice license renewal.

\section{DATA AVAILABILITY}

The data that support the findings of this study are available from the corresponding author upon reasonable request.

\section{Acknowledgments}

The authors are grateful to: Alaa Khalifa, Esraa Mohammed, and Esraa Esmail for participating in questionnaire distribution and support during the development of this manuscript.

\section{Funding}

This study was not funded by any governmental or non-governmental sources.

\section{Conflict of interest}

The authors have no proprietary, financial, or other personal interest of any nature or kind in any product, service, and/or company that is presented in this article.

\section{Regulatory Statement}

This study was conducted in accordance with all the provisions of the local human subject's oversight committee guidelines and policies of: Research Ethics Committee, Faculty of Dentistry, Cairo University. The approval code for this study is: $18-10-52$.

\section{REFERENCES}

1. Carvalho RM, Costa LR, Marcelo VC. Brazilian dental students' perceptions about medical emergencies: a qualitative exploratory study. J Dent Educ. 2008 Nov;72(11):1343-49. doi: 10.1002/j.0022-0337.2008.72.11.tb04617.x.

2. Elanchezhiyan S, Elavarasu S, Vennila K, Renukadevi R, Mahabob MN, Sentilkumar B, et al.. Awareness of dental office medical emergencies among dental interns in southern India: an analytical study. J Dent Educ. 2013 Mar;77(3):364-9. doi: 10.1002/j.0022-337.2013.77.3.tb05480.x.

3. Gonzaga HF, Buso L, Jorge MA, Gonzaga LH, Chaves MD, Almeida OP. Evaluation of knowledge and experience of dentists of São Paulo State, Brazil about cardiopulmonary resuscitation. Braz Dent J. 2003;14(3):220-2. doi: 10.1590/s0103-64402003000300015.

4. Atherton GJ, McCaul JA, Williams SA. Medical emergencies: medical emergencies in general dental practice in Great Britain Part 2: drugs and equipment possessed by GDPs and used in the management of emergencies. Br Dent J 1999 Feb;186(122):125-30. doi: 10.1038/ sj.bdj.4800039a1. 
5. Atherton GJ, McCaul JA, Williams SA. Medical emergencies: medical emergencies in general dental practice in Great Britain Part 1: their prevalence over a 10-year period. Br Dent J. 1999 Jan;186:72-9. doi: 10.1038/sj.bdj.4800023.

6. Fast TB, Martin MD, Ellis TM. Emergency preparedness: a survey of dental practitioners. J Am Dent Assoc. 1986 Apr;112(4):499-501. doi: 10.14219/ jada.archive.1986.0043.

7. Malamed SF. Medical emergencies in the dental office-E-Book. 7th ed. Mosby: Elsevier Health Sciences; 2014.

8. Almahmeed W, Arnaout MS, Chettaoui R, Ibrahim M, Kurdi Ml, Taher MA, et al. Coronary artery disease in Africa and the Middle East. Ther Clin Risk Manag. 2012;8:65-72. doi: 10.2147/TCRM.S26414.

9. Wilson MH, McArdle NS, Fitzpatrick JJ, Stassen LF. Medical emergencies in dental practice. J Ir dent Assoc. 2009 Jun;55(3):134-43.

10. Sopka S, Biermann H, Druener S, Skorning M, Knops A, Fitzner C, et al. Practical skills training influences knowledge and attitude of dental students towards emergency medical care. Eur J Dent Educ. 2012 Aug;16(3):179-86. doi: 10.1111/j.1600-0579.2012.00740.x.

11. Gupta T, Aradhya MR, Nagaraj A. Preparedness for management of medical emergencies among dentists in Udupi and Mangalore, India. J Contemp Dent Pr. 2008 Jul;9(5):92-9.

12. Haas DA. Management of medical emergencies in the dental office: conditions in each country, the extent of treatment by the dentist. Anesth Prog 2006;53:20-4.

13. Müller MP, Hänsel M, Stehr SN, Weber S, Koch T. A state-wide survey of medical emergency management in dental practices: incidence of emergencies and training experience. Emerg Med J. 2008 May;25(5):296300. doi: 10.1136/emj.2007.052936.

14. Broadbent JM, Thomson Wm. The readiness of New Zealand general dental practitioners for medical emergencies. NZ Dent J. 2001 Sep;97(429):82-6.

15. Kufta K, Saraghi M, Giannakopoulos H. Cardiovascular considerations for the dental practitioner. 2. Management of cardiac emergencies. Gen Dent. 2018 Jan-Feb;66(1):49-53.

16. Ghanem E, Elgazar M, Oweda K, Tarek H, Assaf F, Ahmed El-Husseny MW, et al. Awareness of basic life support among egyptian medical students; a cross-sectional study. Emerg (Tehran). 2018;6(1):e36.

17. Wald DA, Wang A, Carroll G, Trager J, Cripe J, Curtis M. An office-based emergencies course for third-year dental students. J Dent Educ. 2018 Aug;77(8):1033-41. doi: 10.1002/j.0022-0337.2013.77.8.tb05572.x.

18. Haas DA. Preparing dental office staff members for emergencies: developing a basic action plan. J Am Dent Assoc. 2010 May;141:S8-S13. doi: 10.14219/jada.archive.2010.0352.
19. Maryam A, Atessa P,Mozafari Pegah M, Zahra S, Hanieh G, Davood A et al. Medical risk assessment in patients referred to dental clinics, Mashhad, Iran (2011-2012). Open Dent J. 2015 Dec 23:9:420-5. doi: 10.2174/1874210601509010420

20. Chapman PJ. Medical emergencies in dental practice and choice of emergency drugs and equipment: a survey of Australian dentists. Aust Dent J. 1997;42(2):103-8. doi: 10.1111/j.1834-7819.1997.tb00104.x.

21. Varma LSC, Pratap KVNR, Padma TM, Kalyan VS, Vineela P, et al. Evaluation of preparedness for medical emergencies among dental practitioners in Khammam town: A cross-sectional study. J Indian Assoc Public Health Dent. 2015 Dec;13(4):422-8. doi: 10.4103/2319-5932.171178.

22. Stafuzza TC, Carrara CF, Oliveira FV, Santos CF, Oliveira TM. Evaluation of the dentists' knowledge on medical urgency and emergency. Braz Oral Res. 2014;28:S1806-83242014000100240. doi: 10.1590/10.1590/18073107bor-2014.vol28.0029.

23. Smereka J, Aluchna M, Aluchna A, Szarpak L. Preparedness and attitudes towards medical emergencies in the dental office among Polish dentists. Int Dent J. 2019 Mar;69(4):321-8. doi; 10.1111/idj.12473.

24. Collange 0, Bildstein A, Samin J, Schaeffer R, Mahoudeau G, Féki A, et al. Prevalence of medical emergencies in dental practice. Resuscitation. 2010 Jul;81(7):915-6. doi: 10.1016/j.resuscitation.2010.03.039.

25. Nandita S, Junaid A, Ravikran O, Boaz K, Srikant N. Are dental surgeons prepared for medical emergencies. Int J Biomed Res. 2013 Dec;4(9):461-4. doi:https://doi.org/10.7439/ijbrv4i9.322.

26. Kumarswami S, Tiwari A, Parmar M, Shukla M, Bhatt A, Patel M. Evaluation of preparedness for medical emergencies at dental offices: A survey. J Int Soc Prev Community Dent. 2015 Jan-Feb;5(1):47-51. doi: 10.4103/22310762.151977

27. Al-Hassan M, Alqahtani S. Preparedness of dental clinics for medical emergencies in Riyadh. Saudi Arabia. Saudi Dent J. 2019 Jan;31(1):115-21. doi:10.1016/j.sdentj.2018.11.006.

28. Goel A, Kroria J. An assessment of Dentist's Knowledge about Medical Emergencies in Punjab. Int J Novel Res in Healthcare and Nursing. 2016;3:141-4.

29. Gbotolorun OM, Babatunde LB, Osisanya 0, Omokhuale E. Preparedness of government owned dental clinics for the management of medical emergencies: a survey of government dental clinics in Lagos. Nig Q J Hosp Med. 2012 Oct-Dec;22(4):263-7.

30. Breuer G, Knipfer C, Huber T, HuettI S, Shams N, Knipfer K, et al Competency in managing cardiac arrest: a scenario-based evaluation of dental students. Acta Odontol Scand. 2016;74(4):241-9. doi: 10.3109/00016357.2015.1042782.

\section{Heba Hussein}

(Corresponding address)

Oral Medicine and Periodontology Department, Faculty of Dentistry,

Cairo University, Cairo, Egypt

Email: heba.said.ismael@gmail.com

Date submitted: 2020 Nov 12

Accept submission: 2020 Nov 24 